
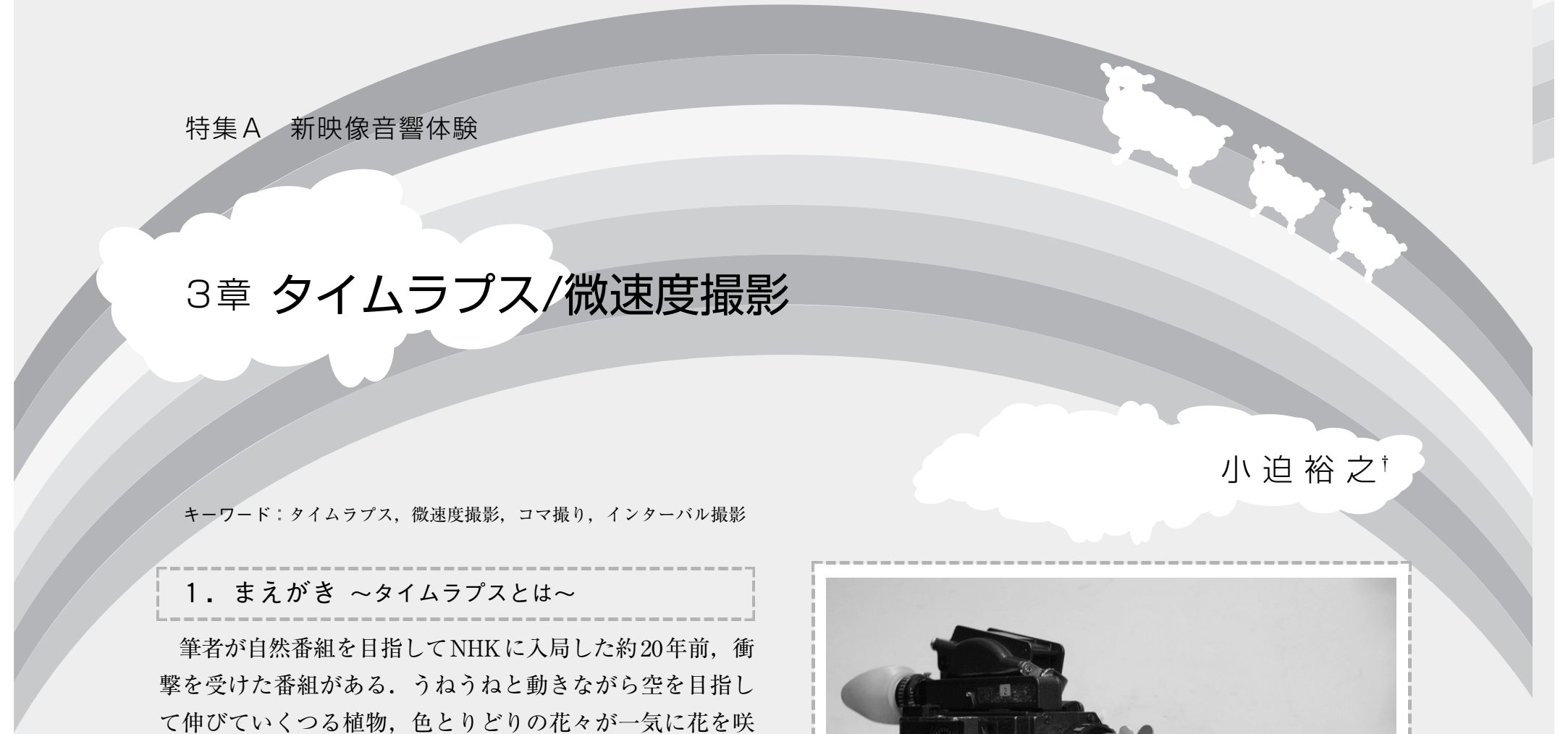

\title{
3章 タイムラプス/微速度撮影
}

\section{1. まえがき 〜タイムラプスとは〜}

筆者が自然番組を目指してNHKに入局した約 20 年前，衝 撃を受けた番組がある.うねうねと動きながら空を目指し て伸びていくつる植物，色とりどりの花々が一気に花を咲 かせ，さらに実になって色づいていく。“確実な意志を持っ て動く”見たことのない植物の世界がそこにはあった，BBC の自然番組の名作「The Private Life of Plants」である. 未知 の世界にいざなってくれる映像の力を感じた瞬間だった。

このように急速に成長していく植物，さらには空を高速 で流れていく雲, 満点の星が動いていく様子など, 通常で は見えにくいゆっくりとした動きを早めて見せる手法を夕 イムラプスと呼んでいる.

動きの速い事象をゆっくりと見せる高速度撮影 (ハイス ピード撮影)に対して, 微速度撮影とも呼ばれている. ディジタルスチルカメラの登場とともに, 映像業界では一 般的な手法としてさまざまな場面において用いられてき た。一般的にはコマ撮りやインターバル撮影などとも言わ れ，インターバル撮影機能自体がカメラに内蔵されること も増え, 一般の人々の間でも可能な撮影手法となってきて いる.

一方でその使用法は，時間を短縮することで見えない世 界を可視化するという科学的な目的だけでなく，独特な世 界観を映像化したり，人間の尺度とは違う時間を表現した りと映像表現の手法の一つとして重要な撮影技法と位置付 けられている。

\section{2.タイムラプス機材とその変遷}

フィルムカメラ全盛時代にはカメラの機構的特徵から夕 イムラプスという手法は多く用いられていたが，その後ビ デオカメラが登場するとタイムラプス撮影が一時的に停滞 した時期がある. ビデオカメラは撮像管や撮像素子で光を 電気信号に変換しテープに磁気的に記録するものだが，そ の光の変換や記録のスピードを可変することが原理的に難

$\dagger$ NHK 大阪放送局 技術部
"Time Lapse" by Hiroyuki Kozako (Technical\&Engineering Division,
Osaka Station, NHK, Osaka)

658 (18)

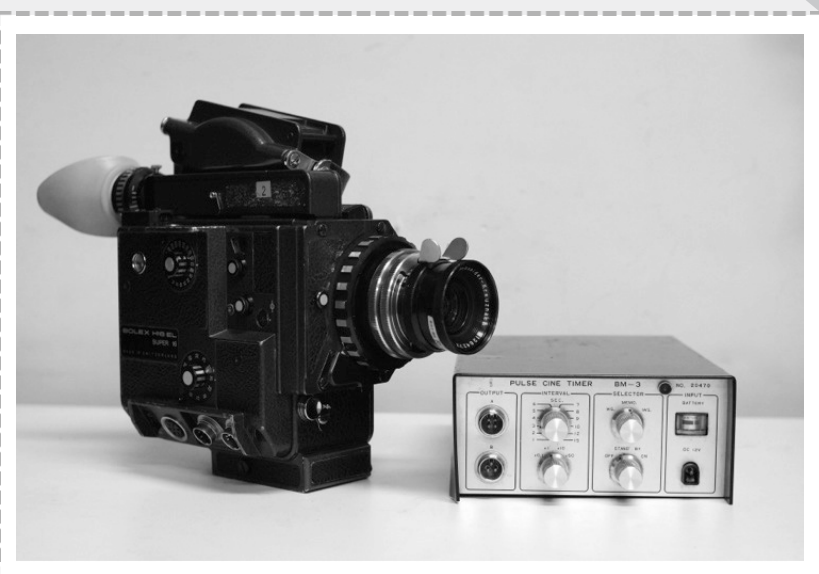

図 1 NHKの科学番組でタイムラプス機材として活躍したBOLEX H16 EL スーパー 16 mmフィルムカメラとPULSE CINE TIMER BM-3

小迫裕之

しいことが要因である。その後ディジタル技術の進化によ りメモリーへの一時保存が可能となり，時間をコントロー ルすることが可能となった。今では放送用ビデオカメラに もインターバル REC 機能が内蔵され，タイムラプス機能が 内蔵されたディジタルスチルカメラやスマートフォンも登 場している．筆者がこれまで使用してきた撮影機材を中心 に，年代順にその撮影機材と変遷を紹介する.

(1) フィルムカメラ (35 mmカメラや $16 \mathrm{~mm}$ カメラなど)

フィルムカメラはもともと写真の連続撮影によって実現 されたものであり，カメラによっては早回しや遅回しなど 1 秒当たりの撮影コマ数を可変できる機種があった (図 1). (通常の撮影コマ数は 1 秒あたり 24 枚や 30 枚であるが，秒 間500コマの速回しや秒間 1 コマの遅回しなど) 今のビデオ カメラと違い機構的に微速度撮影に向いていた．前述した $\mathrm{BBC}$ の番組もフィルムカメラを使用して撮影されたもので ある。

(2) フィルムスチルカメラと長尺マガジン

1996年，筆者が長期間のタイムラプス撮影に使用した. 当時のフィルムスチルカメラは 36 枚撮りのフィルムを使用 するのが一般的であったが，250枚撮影可能な長尺マガジ ンに変更し稲の成長の様子を狙った。時間を変えて 1 日 4 枚の写真を撮影. 2 カ月ごとにフィルム交換を行い，約半

映像情報メディア学会誌 Vol. 69, No. 7, pp. 658～664（2015） 


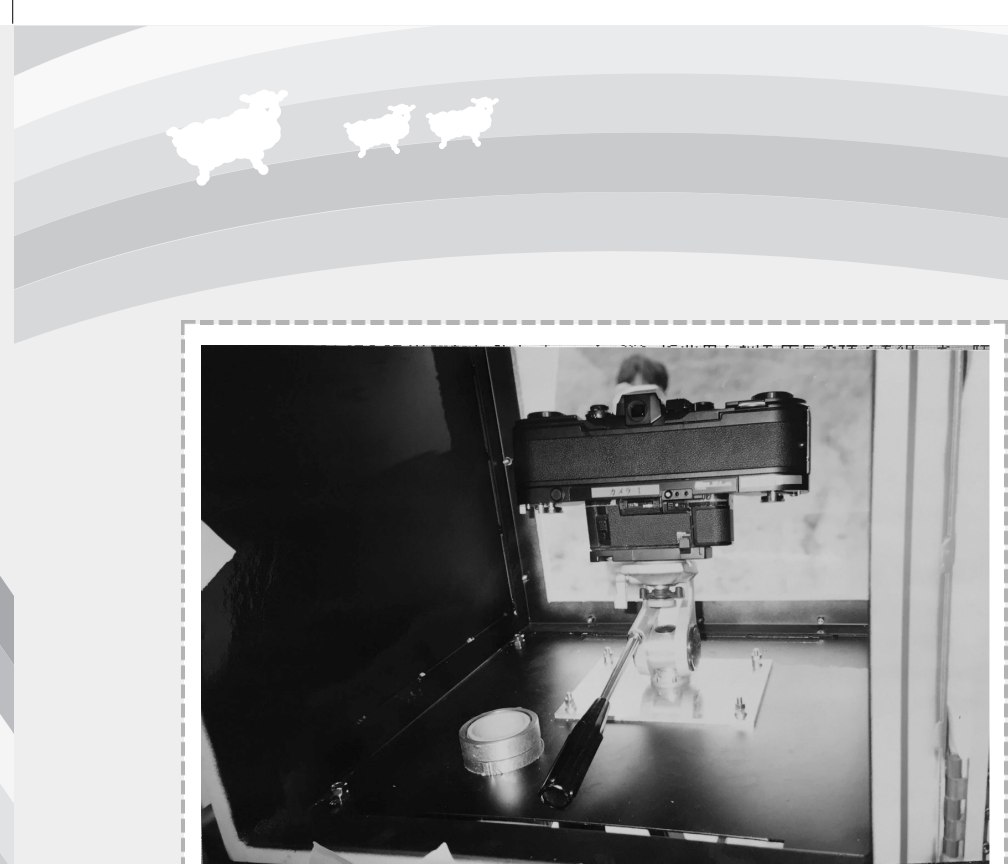

（a）長尺マガジンを装着したニコンF3カメラ

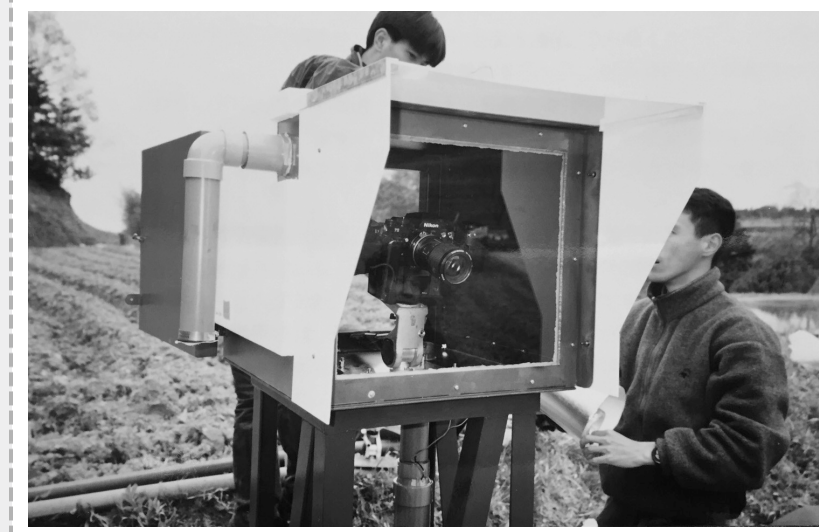

（b）防水ケースを製作し長期間にわたり撮影を行った

図2 フィルムスチルカメラを使用したタイムラプス事例

年間撮影を行った (図 2 (a)，（b))。後日選択した写真をス キャンすることにより動画化を行った。

現在のディジタルスチルカメラではメモリー次第で数万 枚の写真が撮影可能で，この 20 年の進化には驚かされる.

(3) ハイビジョンコマ撮り装置 (1997年)

ハイビジョンカメラの映像出力を本体に入力し, 静止画 として取り込む装置をNHKが開発した（図3). 本体にメモ リーが内蔵され，取り込んだ静止画を装置内で動画化する 機能を備える. 動画化された映像を外部 VTRで収録する.

(4) ハイビジョンカメラ内藏機能

2001年に発売されたりニー製ハイビジョンカメラ HDW750 にインターバル REC 機能が付加された（実際には HKDW-703内蔵ボードにより実現）(図4).カメラ単体で タイムラプスが可能となったことは画期的なことであっ た. 現在も現役機種として活躍中.

(5) ディジタルスチルカメラとタイマリモートコント ローラ

現在でも最も多く使用している撮影機材．タイマリモー トコントローラからディジタルスチルカメラにシャッタ信 号を送ることにより写真を一定間隔で撮り続ける（図5). 撮影した連続写真を映像加工ソフトなどで動画化する。 セ

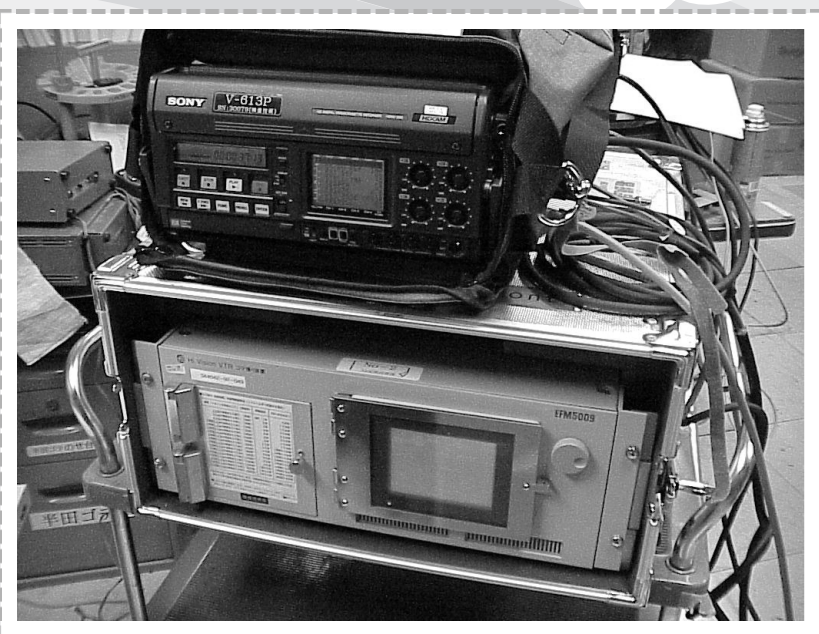

図3ハイビジョンコマ撮り装置 (下部)
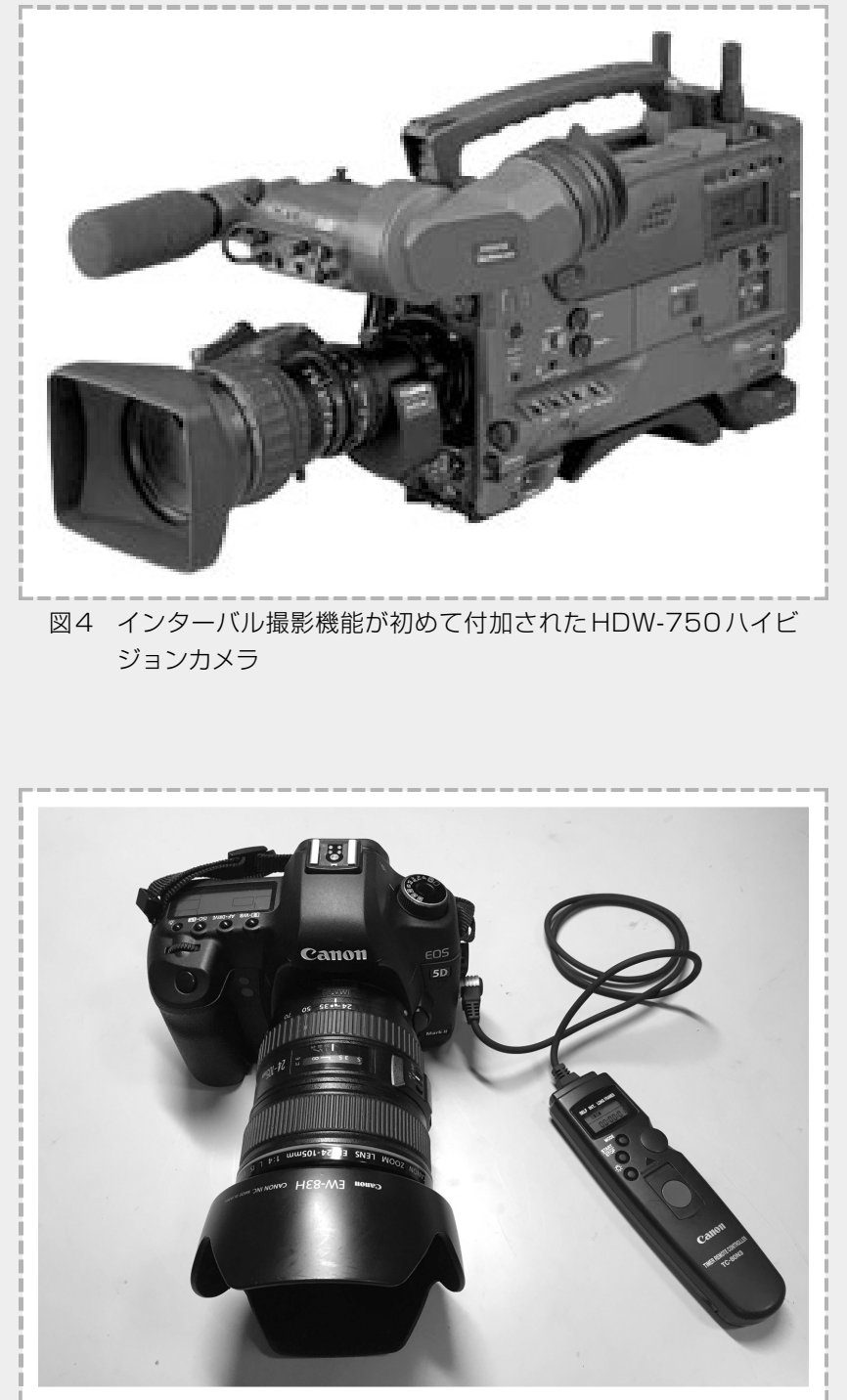

図5 ディジタルスチルカメラとタイマリモートコントローラの一例

ンサ解像度がハイビジョンの 200 万画素を越えた 2000 年頃 から放送業界でも使用され始めた。

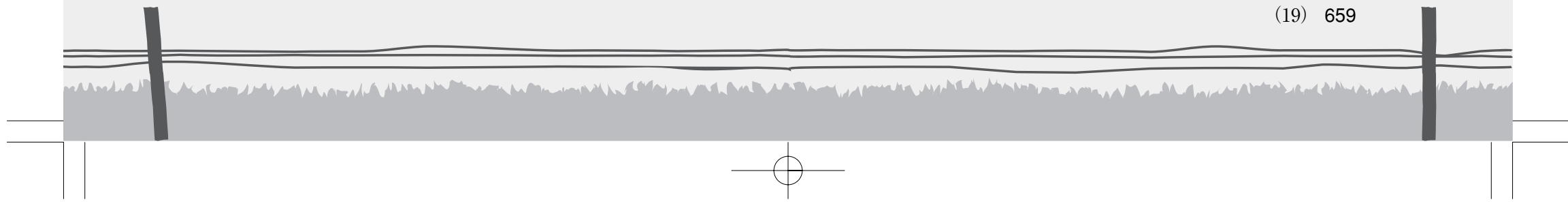



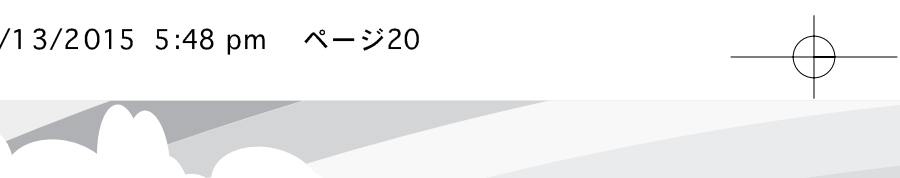

特集 $\mathrm{A}$ 新映像音響体験

(6) 民生カメラ内蔵機能

近年タイムラプス機能が内蔵されたデイジタルスチルカ メラやディジタルビデオカメラが登場. Goproやソニーア クションカムなどの小型カメラにもインターバル撮影機能 が内蔵されている。またプロ用の一眼レフデジカメにも同 様の機能を持つものがあり，ニコンのディジタル一眼レフ カメラにはインターバル撮影 (連続写真撮影) とともに, 微 速度撮影として動画を作成するモードを持つものもある.

(7) iPhone6内蔵タイムラプス機能

2014 年に発売されたiPhone6にはカメラの内蔵機能とし てタイムラプス機能が追加された (正確にはiOS8 の機能) (図6)。それ以前の機種やアンドロイドスマートフォンで もアプリの追加によりタイムラプスが可能であったが，内 蔵されたことでタイムラプスにより親しみやすくなった。

iPhone6 の内蔵機能の場合, 撮影間隔は一定ではなく, トータルの撮影時間により変化する.

\section{3. タイムラプスの具体的手法}

前節で紹介した数々の撮影機材のなかで，タイムラプス 機材として最も沉用性があり一般化しているのは, ディジ タルスチルカメラとタイマリモートコントローラによる手 法である。

雲の動きや花の開花といった数十分から数時間にわたる 撮影から，半年や 1 年といった長期にわたる撮影まで幅広 く対応できる．撮影機材自体の価格が安いため複数台を同 時に使用したり, また解像度も日々高画素化しているため, トリミングや写真内でのズームやパンなど高画素ならでは の映像効果も期待できる.

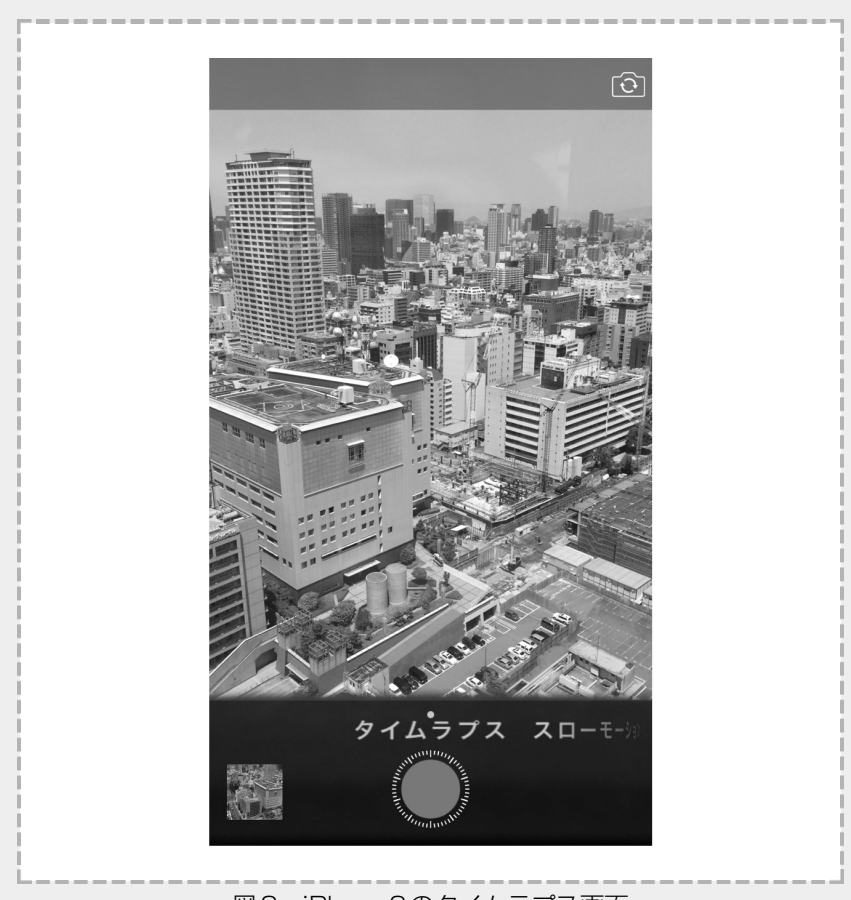

図6iPhone6のタイムラプス画面

$660 \quad(20)$
ディジタルスチルカメラを使用したタイムラプスの具体 的手法を動画化も含めて紹介する.

\section{1 カメラの設定}

(1) 撮影画素数

放送を前提とすればハイビジョン解像度の 200 万画素以 上であれば問題はない. トリミングやパンなど映像加工を 行う場合は高画素で撮影する。高画素になれば1枚あたり のファイル容量も大きくなるため, 撮影時間と撮影枚数, 保存先のハードディスク容量など総合的に判断することが 重要である。

(2) 撮影モード

基本的にはマニュアルモードを使用する．明るさが大き く変化する時間帯をまたいで撮影する場合などは絞り優先 モードなどオートモードでの撮影も可能だが，仕上がり映 像にちらつきが出ることがあるので注意が必要である. ディジタルスチルカメラによっては, 露出平準化機能 (前 後の露出差を少なくする機能)を持つものもある.

\section{(3) 撮影間隔}

タイマリモートコントローラで撮影間隔を設定する．写 真 30 枚で 1 秒の動画が作成できる。トータル撮影時間と撮 影枚数，仕上がり動画時間を計算して撮影間隔を設定する. タイムラプス設定のためのスマートフォンアプリもあるの でそれを利用するのも一つの方法である.

図7は15秒に1回シャッタを切る設定である.1分に4枚, 1 時間で 240 枚の写真を撮影することになる．240枚の写真 は8秒分の動画に変換できる.つまり 1 時間を 8 秒の動画に する設定である。

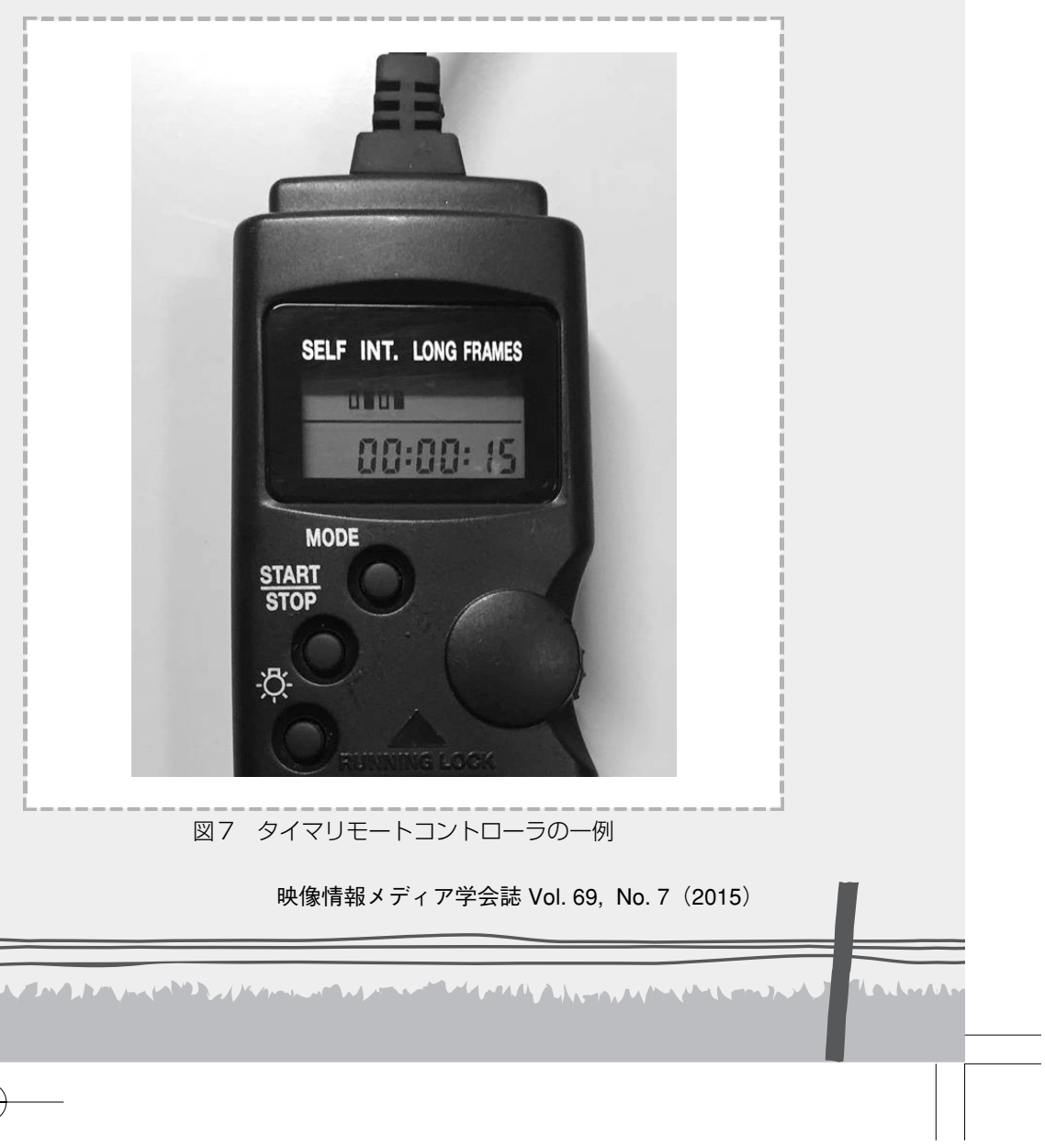




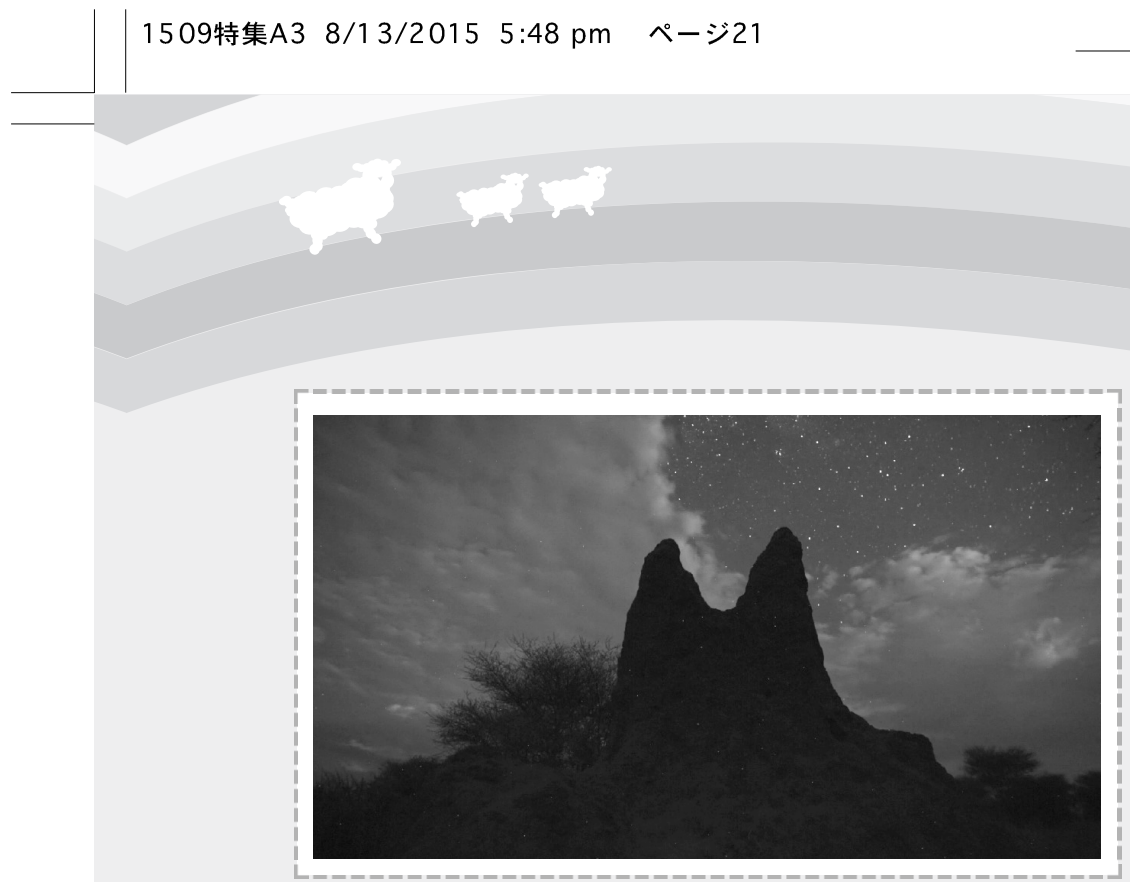

図8 星空と雲 はっきりとした雲はコマ撮りに向いている

\section{2 撮影の条件}

前記のように設定自体に難しさはない，経験的に言える ことは, どのタイミングでどういう条件で撮影を行うかが 重要となる。

例えば，雲の動きを撮影する場合，仕上がり映像の良し 悪しは雲の状態 (はっきりとした雲かぼんやりとした雲か) や雲の流れる方向, 時間带などによって印象はまったく違 うものになってしまう.

また花の開花では，風の影響によって花が摇れてしまう と開花自体よりも風によるちらつきばかりが気になってし まう. また風のない場所でも植物は思った以上に動くので, 花のアップを撮影する場合には画角から外れないような工 夫が必要となる.

星のコマ撮りでは意外にも月の影響が非常に大きい。満 月など明るい月が出ている状態では，まず星は映らない. 星のコマ撮りを計画する際にはまず，月齢を調べてから撮 影日程を決める必要がある。もちろん雲の影響も大きい. 一見晴れているように見えても薄雲がかかっていれば近く の街明かりが反射して星は見えない。一方ではっきりした 雲は星空のアクセントとしては非常に有効な撮影対象とな り得る (図8).

タイムラプスは難しい，何度経験しても行きつく答えで ある. 特に自然状態ではいつも条件が異なり,これが正解 というものはない. 積み重ねた経験からその場の状況を判 断するしか方法はない.

\section{3 動画化}

連続写真の動画化にはいくつかの方法がある. Adobe Premiere, Apple Final Cut Pro等の映像編集ソフトを使用 する方法もあるが, 経験上効率良く映像化が可能なのは Appleのソフト QuickTime Player 7 Proを使用する方法で ある.「イメージシーケンスを開く」から画像ファイルを選 択することにより短時間で動画化され，できた映像をすぐ に確認できる(図9)。この時点でまだ動画ファイルはでき ていないので書き出しにより映像フォーマットなどを設定 し動画化を行う。

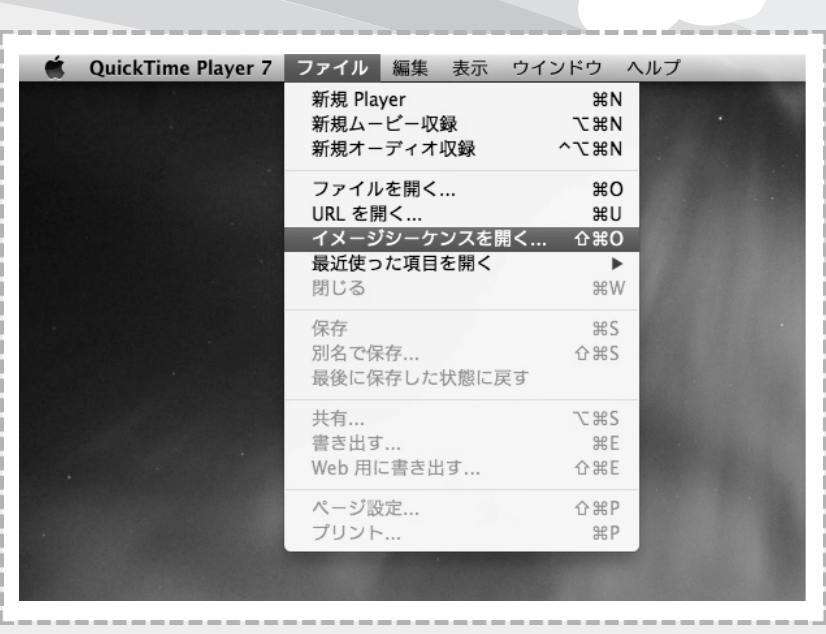

図9 QuickTime Player 7 Proによる動画化の一例

以上のように, タイムラプスの手法自体に難しさはない. 映像の良し悪しを決めるのは, やはりどの夕イミングでど う切り取るかの見極めである。これは通常の撮影とまった く同じである．ただ，通常は気付かないようなゆっくりと した動きがタイムラプスによってダイナミックに表現でき るものもあるので，そこには経験が必要になってくる.

\section{4.【応用編】移動微速度撮影}

パンやチルト，レールドリーといったカメラの動きを夕 イムラプスと組合せる手法がある。ゆっくりと動く雲台や ゆっくりと移動するレールといった特別な装置が必要で モーションコントロールシステムと呼ばれる(コンピュー 夕制御によってカメラの動きを何度でも再現できるモー ションコントロールカメラの一種とも言えるが，用途と規 模が異なるので区別している).

以前は撮影に合わせて移動撮影用の機材を製作するとい うことが多かったが，最近は世界のさまざまなメーカで簡 易なモーションコントロールシステムが開発されており， 簡単に入手することが可能となっている (図10～図 12). $45^{\circ}$ のパンの動きを 1 時間かけてゆっくり動かしたり， $1 \mathrm{~m}$ のレールの動きを 3 時間に設定したりと撮影意図によって パンやチルト，レールの動きをそれぞれ設定していき， シャッタやフォーカスといったデイジタルスチルカメラの

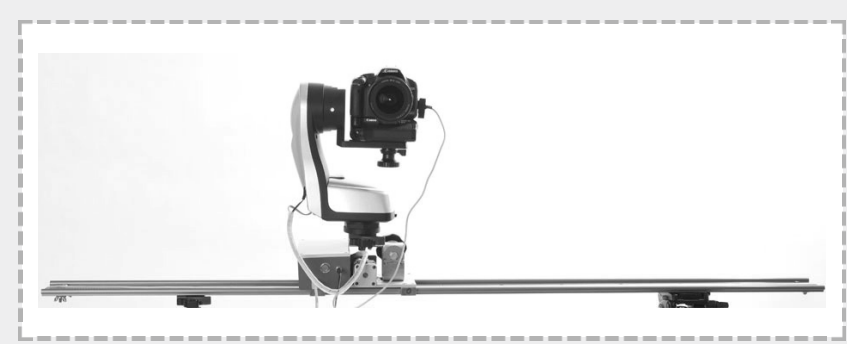

図 10 Motiontimer スペイン製のモーションコントロールシステム

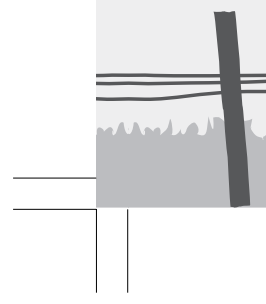

(21) 661 
特集 $A$ 新映像音響体験

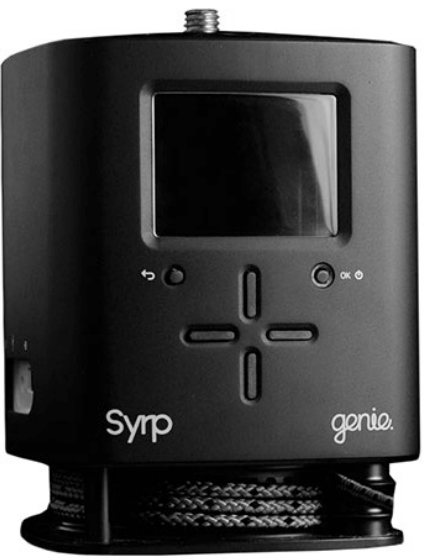

図 11 Syrp genie ニュージーランドSyrp社製 制御は 1 軸のみであるが，下部のマウントを変更することでパンと レールドリーのどちらかを選択できる

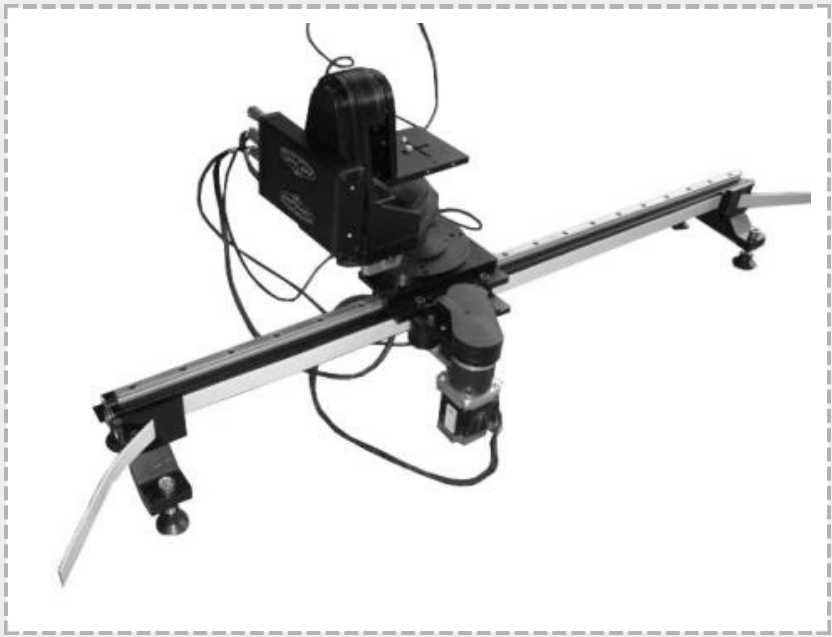

図 12 Mark Roberts SFH-30

国際的にも実績のあるMark Roberts社製システムで，マニュアルで 行った動きを何度でも再現できるほか，時間を引き延ばして動かすこ とができる(例えば，30秒の一連の動きを 1 時間かけて動かすなど)．

制御ができるものもある.

次に筆者が実際に行った移動微速度撮影の例を二つ紹介 する.

4.1 Motiontimer 使った事例

ナミブ砂漠に生息するシロアリとキノコの共生関係の長 い歴史を描くシーンに用いた (図13). ナミビアの生態系に おいて核となるシロアリ．なかでもキノコシロアリはアリ 塚の中でキノコを育て食糧にするという独特の生態を持っ ている.キノコは砂漠という極度に乾燥した土地でありな がらアリ塚内部という湿度がコントロールされた場所での 生育が可能で, さらにシロアリの結婚飛行（アリ塚内で生 まれた女王アリ候補が外に旅立っていく行為）によりキノ コの胞子は遠くに運ばれ，子孫繁栄にもつながっている.

(1)アリ塚に思いが行くように, レールで近づきながら

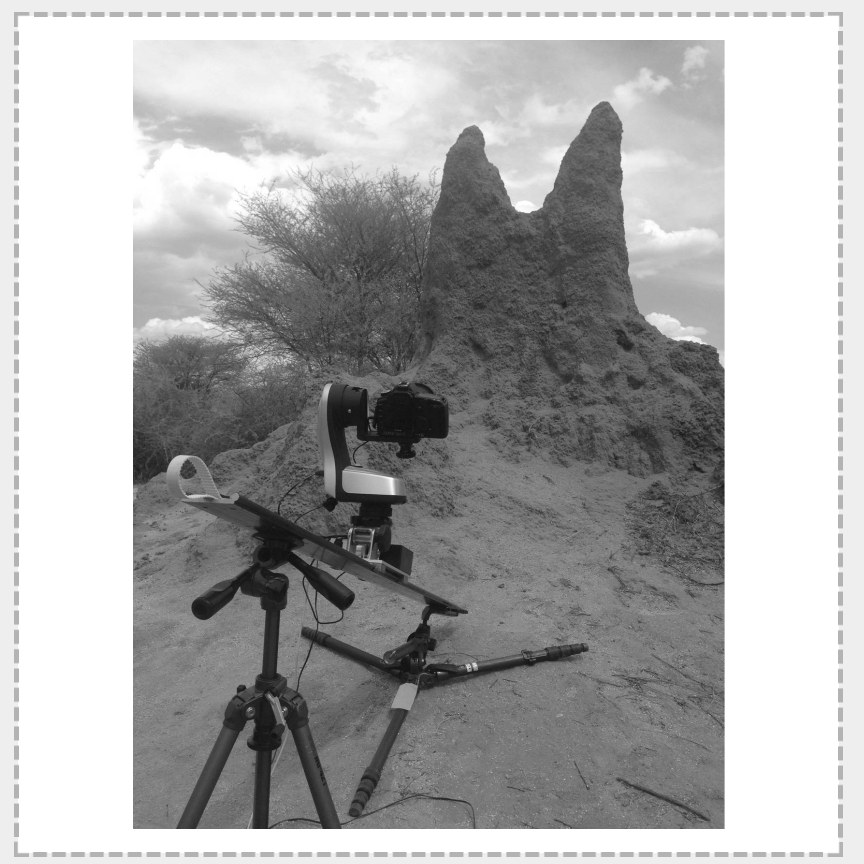

図 13 Motiontimerを用いた移動微速度撮影

チルトアップしてアリ塚を見上げるように強調して いく.

(2) 昼，夕方，夜の 3 回にわたり，同じ動きをタイムラプ ス撮影し，後処理でオーバラップしていく.

（1），(2）を組合せることにより，「アリ塚の強調」と「人 間の尺度とは違う時間の表現」という二つのことを 1 カッ トに凝縮できたと思っている。

\section{2 円形微速度レールを用いた事例}

ブラジルの中央部に広がるセラードという場所に林立す るアリ塚を中心とした世界をタイムラプスという手法で表 現した.

セラードにはシロアリを主食とするオオアリクイやアル マジロ，アリ塚に穴を開けて子育てをするアリ塚ゲラ (キ ツツキの一種) などシロアリやアリ塚を頼りにして生きる 生き物がたくさんいる。またアリ塚の表面にあいた小さな 穴のなかにはヒカリコメッキというコメッキ虫の幼虫が棲 んでおり, 雨期の夜, 虫をおびき寄せて食べるためにその 幼虫が一斉に光る様は, 日本のホ夕ルを思わせとても幻想 的である。このようにアリ塚を中心に回っている世界を “象徵的”に表現するために, 円形微速度レールによる夕イ ムラプスという手法に挑戦した (図 14)。なお，この移動 微速度撮影システムはNHKと有限会社不二技研が共同で 開発したものである(図 15).

セラードの中心であるアリ塚をめぐるドラマチックな 日々を 1 カットに凝縮して見せるためさまざまなシチュ エーションで撮影を行った (図15)。昼，夕方，夜，雨雲が 迫り雨に変わっていく様子, 乾季落雷による発火でアリ塚 が炎に包まれる様子，雨季に光輝くアリ塚など約 1 年にわ

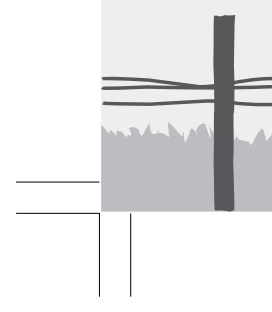
$662(22)$

映像情報メディア学会誌 Vol. 69, No.7 (2015) 


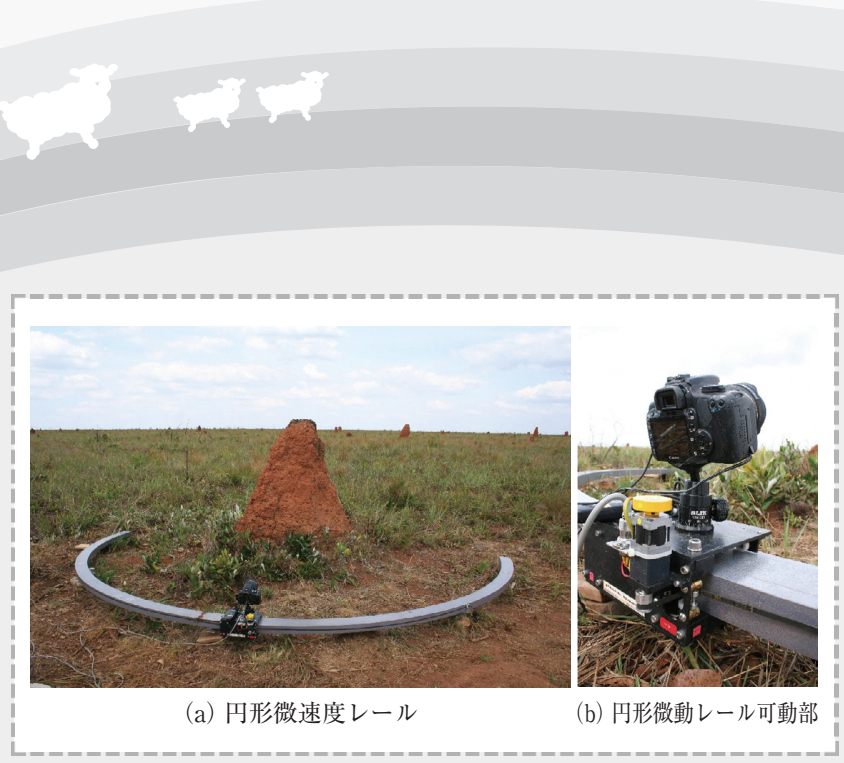

図14 円形微速度レールを用いたタイムラプス事例
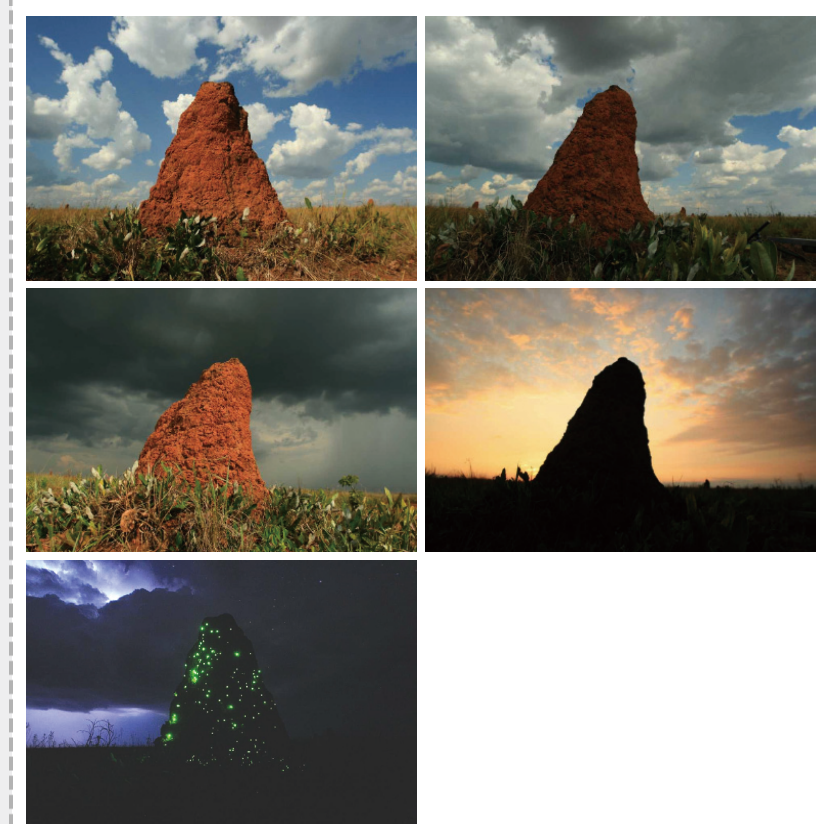

図 15 アリ塚を中心にさまざまなシチュエーションで撮影

たり， $720^{\circ}$ ，2周にわたってその時々に撮影を行った。多 くの時間と労力を伴ったが，アリ塚を中心に回る世界を “象徵的”に1カットで見せることができた.

\section{5.【応用編】高感度微速度撮影}

満天の星空は肉眼でははっきりと見えるが，それを鮮明 に映し出すビデオカメラは未だに存在しない。一方で長時 間露光による写真撮影では人間の眼よりさらに鮮明に星空 を映し出すことが可能である．昨今のディジタルスチルカ メラの高感度化により, 星空の写真撮影はより身近なもの となってきた，その高感度写真撮影とタイムラプスを組合 せたものが, 高感度微速度撮影である. “空いっぱいに動 いていく満点の星空”，そんな映像を読者の方も一度は見 たことがあるのではないだろうか.

他にも，肉眼では見えるがビデオカメラでは撮影が難し

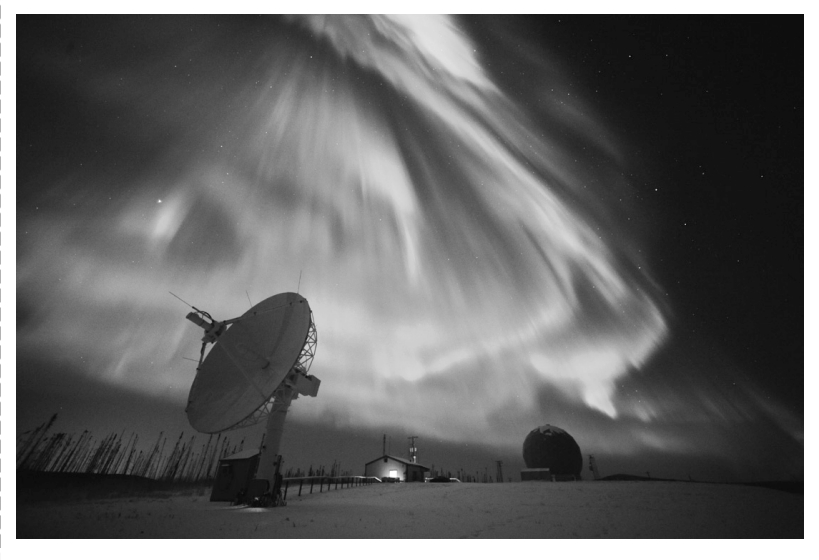

図 16 アラスカで撮影したオーロラ (感度IS06400, 絞り f2.8, シャッタスピード2秒)

表 1 同一露出時のISO感度, 絞り值, シャッタスピードの関係

\begin{tabular}{|c|c|c|}
\hline ISO感度 & 絞り值 & シャッタスピード \\
\hline \hline 1600 & 4 & 32 秒 \\
\hline 6400 & 4 & 8 秒 \\
\hline 6400 & 1.4 & 1秒 \\
\hline 12800 & 1.4 & 0.5 秒 \\
\hline
\end{tabular}

いオーロラの撮影 (図 16), 微弱な光を放つキノコの撮影 など高感度写真撮影とタイムラプスを組合せた撮影はさま ざまなシチュエーションで行われている.

撮影機材の選定には下記のような条件が重要となる.

(1) ISO感度の高いディジタルスチルカメラを使用する.

(2) 絞り開放值の明るいレンズを使用する.

センサISO感度は日々進化している，最新機種では常用 ISO 感度 102400 の高感度カメラも存在するが, 経験上 ISO6400〜 12800程度に抑えることが望ましい.レンズの 開放值についてはf1.4などの明るい単焦点レンズが最適. 表1のように，ISO感度と絞り值が高いほど，シャッタス ピードは短くなり，撮影には有利となる.

筆者も 10 年来にわたり高感度微速度撮影を行ってきた. なかでも思い出深いのは前項でも触れた光るアリ塚の撮影 である. 光の強さはホ夕ルほどで, 肉眼では無数に見える 光も当時最新の高感度ビデオカメラ (ハイビジョンスー パーハープカメラ，アイアイカメラなど）をしてもその感 動を映像で伝えることは困難であった。 そこでディジタル スチルカメラによる高感度撮影に注目し, タイムラプスと 組合せることで無数に光輝くアリ塚を見た目の感動以上に 映像で伝えることができた(図 17).

さらに前述した円形微動レールと組合せることで想像も しなかった印象的なカットを撮影することができた1).

高感度微速度撮影と円形レールを組合せるというアイデ アを思いついたのは実はロケの最中，現地ブラジルでのこ

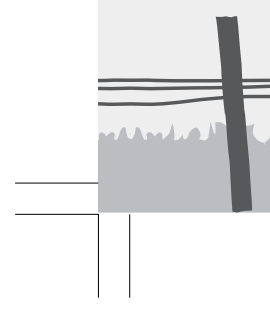

(23) 663 


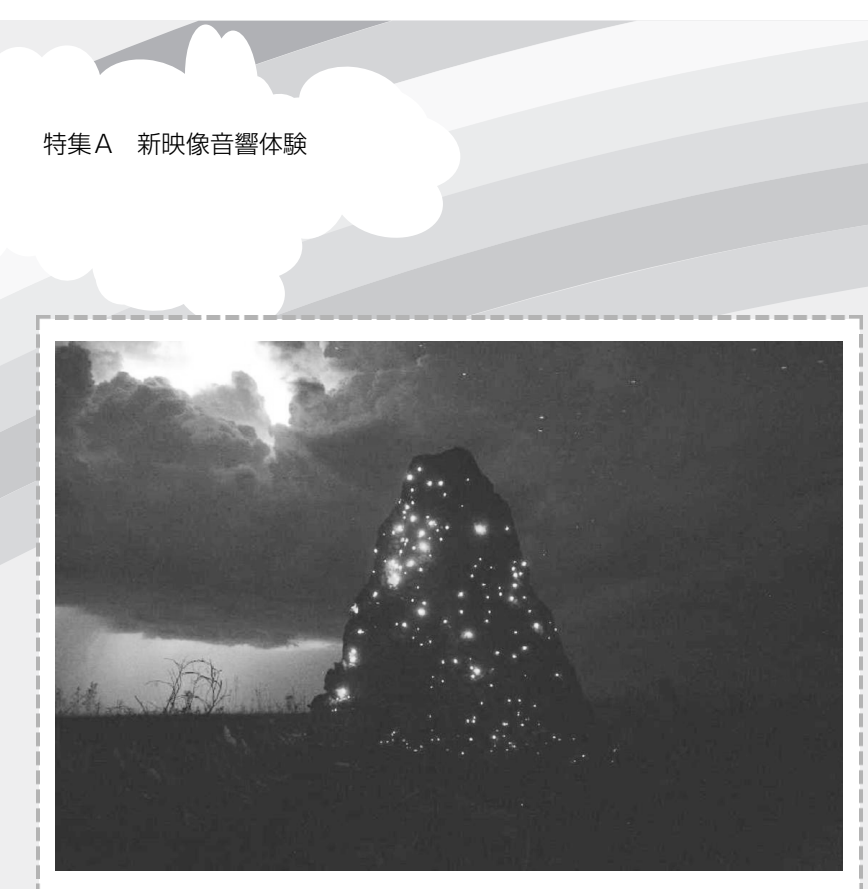

図 17 高感度微速度撮影した光るアリ塚

とであった．以前開発していた直線レールによる微速度撮 影機材を改良し, 円形レールを現地ブラジルで製作した。

完成したその夜は雷の鳴り響く最悪の状況であった。これ までの経験から雨が激しく降る夜にはヒカリコメッキの幼虫 は光らないということがわかっていたので，普段なら撮影を あきらめていたところであるが，この日は動きのチェックの ためにとりあえずテスト撮影を行った，翌日撮影された何千 枚にも及ぶ写真をパソコンで簡易的に映像化してみたとこ ろ，そこには予想外のものが映し出されていた。

四方八方で響きわたる雷，それに照らし出された雷雲が 渦をまいて動き，それはまるで生きているかのようであっ た．そしてその中心にそびえ立つアリ塚は堂々として威厳 があり，なおかつコメッキムシの幼虫はいつにも増して強 い光を放っていた．多分こういう条件が揃うことは一年に 一度あるかないかのことだと思う。まるでCGで描いたよ うな“あり得ない世界”がそこには映し出されていた。

\section{6. むすび}

連続して撮影された写真をもとに映像を作っていくとい うタイムラプスの手法は，〈しくも映画やテレビが始まっ たころのフィルムカメラの原理と似通っている. 非常に原 始的な手法である。違いは時間の尺度である。ありのまま の世界を見せるか, 人間とは尺度の違う時間で見せるか.
ここには単なる早回しという言葉以上のある種の思想が隠 されているょうに思う。

BBCの番組に「The Restless Year」というものがある. イギリスのありふれた田園地帯を描いた番組であるが，全 編が高速度撮影 (ハイスピード撮影) と微速度撮影 (タイム ラプス), 定点撮影で構成されている。 それらの手法によ り, 何気ない日常に光が当てられ，一つ一つが光り輝くも のとして描かれていく. 畑で急速に育っていく野菜や花々， 巣作りから雛の巣立ちまでッバメの生態が定点撮影で次々 と変化していく．クリケットの試合はハイスピード撮影に より叙情的に描かれるとともに，休悡中のアフタヌーン ティーはコマ撮りでコミカルにと，なにげない日常を視点 (時間の尺度)を変えて見ることで，この世界がいかに美し く，知らないことに満ち溢れているという感動を番組全体 を通して表現している．われわれ人間がいかに限られた眼 で世界を見ているかを逆説的に表現した番組とも言える。

冒頭に書いたように，タイムラプスとは「通常では見え にくいゆっくりとした動きを早めて見せる手法」であるが, 視点を変えるという意味で言葉以上の表現力を秘めたもの でもある。

日々のディジタル技術の進化により，タイムラプスとい う手法はより身近で簡便なものとなった．今後も想像がつ かないような機材や技術が開発されていくかもしれない.

しかし，画家が絵筆一つで対象と向き合い，何を思い， 何を描くかというテーマ性で勝負しているように，タイム ラプスという手法も一つの技法として何を描くかにかかっ ている．映像のプロフェッショナルとして今後もそこを突 き詰めていきたいと思う.

(2015年 5 月 18 日受付)

\section{〔文 献〕}

1）小迫裕之：“ブラジル，マダガスカルそして日本へNHKスペシャル 「ホットスポット最後の楽園」取材記”，月刊「放送技術」，64，10 (2011)

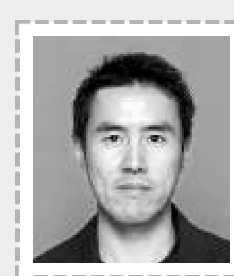

小迫裕定 1994 年, 早稲田大学大学院理工学研 究科機械工学修了. 同年, NHK入局. 入局以来一貫 してカメラマンとして番組制作に携わってきた。 NUKスペシャル『馈像詿里山!シリーズ, NUKスパ シャル『ホットスポット最後の楽園』シリーズなど特 撮技術を用いた自然番組制作を担当

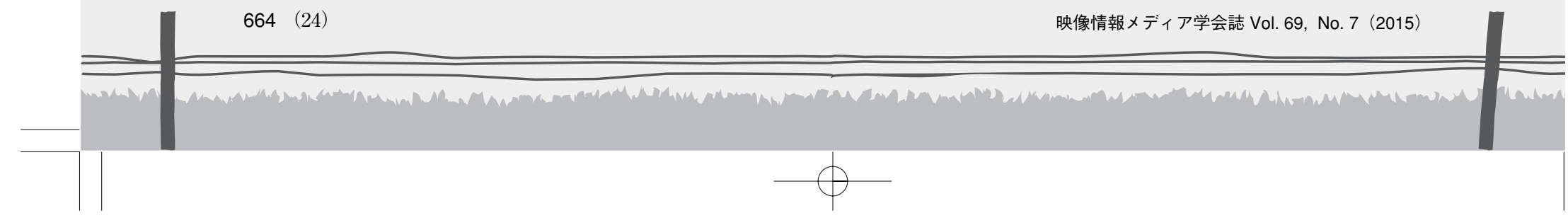

